\title{
Plasmodium malaria and antimalarial antibodies in the first year of life
}

\author{
KATHERINE R. DOBBS ${ }^{1}$ and ARLENE E. DENT $T^{1,2} *$ \\ ${ }^{1}$ Division of Pediatric Infectious Diseases, Department of Pediatrics, Rainbow Babies and Children's Hospital, Cleveland, \\ $O H, U S A$ \\ ${ }^{2}$ Center for Global Health and Diseases, Case Western Reserve University, Cleveland, OH, USA
}

(Received 6 October 2015; revised 30 October 2015; accepted 2 November 2015; first published online 8 Fanuary 2016)

\section{S U M M A R Y}

Malaria is one of the most serious infectious diseases with most of the severe disease caused by Plasmodium falciparum (Pf). Naturally acquired immunity develops over time after repeated infections and the development of antimalarial antibodies is thought to play a crucial role. Neonates and young infants are relatively protected from symptomatic malaria through mechanisms that are poorly understood. The prevailing paradigm is that maternal antimalarial antibodies transferred to the fetus in the last trimester of pregnancy protect the infant from early infections. These antimalarial antibodies wane by approximately 6 months of age leaving the infant vulnerable to malaria, however direct evidence supporting this epidemiologically based paradigm is lacking. As infants are the target population for future malaria vaccines, understanding how they begin to develop immunity to malaria and the gaps in their responses is key. This review summarizes the antimalarial antibody responses detected in infants and how they change over time. We focus primarily on Pf antibody responses and will briefly mention Plasmodium vivax responses in infants.

Key words: Infant, malaria, antibodies, pregnancy-associated malaria.

\section{INTRODUCTION}

Plasmodium falciparum (Pf) malaria is one of the most important paediatric infectious diseases estimated to kill over 600000 people annually, most of whom are children younger than 5 years of age (WHO, 2014). Yet, newborns and young infants (less than 6 months of age) are thought to be relatively protected from symptomatic malaria (Covell, 1950; Wagner et al. 1998; Riley et al. 2001; Apinjoh et al. 2015). This protection historically has been thought to be primarily mediated by maternal antimalarial $\operatorname{IgG}$ antibodies transferred to the fetus in the last trimester of pregnancy. Antibodies play an important role in the host defence against malaria. This was demonstrated when serum transferred from healthy malaria immune adults to hospitalized children with malaria resulted in the rapid amelioration of symptoms and parasitaemia (Cohen et al. 1961; McGregor, 1964). Malaria targets of protective antibodies include proteins expressed on the sporozoite needed for hepatocyte invasion, proteins expressed on the merozoite surface important for invasion of erythrocytes and variant surface antigens (VSAs) trafficked to the surface of the infected erythrocyte important for sequestration and pathogenesis (Richards and Beeson, 2009; Dups et al.

* Corresponding author. Center for Global Health and Diseases, Case Western Reserve University, Biomedical Research Building \#430, 2109 Adelbert Road, Cleveland, OH 44106, USA. E-mail: arlene.dent@case. edu
2014; Smith, 2014). Antimalarial IgG antibodies may function to block sporozoite invasion of hepatocytes and merozoite invasion of erythrocytes, opsonize merozoites and infected erythrocytes expressing VSA on their surface for phagocytosis, and fix and activate complement on the merozoite surface with resultant parasite lysis (Hill et al. 2013). An increasing number of Pf antigens have been identified as relevant to naturally acquired immunity and are considered potential vaccine targets (Richards et al. 2013; Osier et al. 2014; Dent et al. 2015), but how and whether antibodies to these antigens are acquired during the first year of life is not well described. With this review, we focus on maternal antibodies directed against Pf targets and their possible role in protecting the infant from malaria, infant susceptibility to malaria as maternal antibodies wane and infant-generated antimalarial antibodies as a result of malaria infection.

\section{PF MALARIA INFECTION IN NEONATES AND INFANTS}

Infants living in malaria endemic areas are relatively protected from clinical malaria during the first 6 months of life. However, there are instances of malaria infection in neonates. For example, congenital malaria occurs after transmission from the mother through the placenta just before or during delivery (though earlier in pregnancy cannot be excluded), with detection of asexual parasites in cord blood or in neonatal peripheral blood within

Parasitology (2016), 143, 129-138. C Cambridge University Press 2016. This is an Open Access article, distributed under the terms of the Creative Commons Attribution licence (http://creativecommons.org/licenses/by/4.0/), which permits unrestricted re-use, distribution, and reproduction in any medium, provided the original work is properly cited. 
the first week of life (Malhotra et al. 2006; Falade et al. 2007). Neonatal malaria occurs during the first 28 days of life and is due to an infective mosquito bite after birth. Both congenital and neonatal malaria infections are considered to be very rare (Covell, 1950; Bruce-Chwatt, 1952). Though existing data on prevalence and burden of disease in young infants are still limited and often contradictory (Mwaniki et al. 2010), it appears that while subclinical asymptomatic infection is not uncommon, clinical disease due to $\mathrm{Pf}$ infection is quite rare in infants under 5 months of age (Sehgal et al. 1989; McGuinness et al. 1998; Snow et al. 1998; Franks et al. 2001). Several studies in sub-Saharan Africa demonstrate an increase in malaria prevalence and risk for clinical disease after the ages of 3-6 months (Bruce-Chwatt, 1952; Gottschau and Hogh, 1995; McGuinness et al. 1998; Snow et al. 1998; Afolabi et al. 2001).

In malaria endemic regions where mothers have existing immunity, Pf infection in young infants (less than 6 months) is characterized by low parasitaemia, often $<100$ parasites $\mu \mathrm{L}^{-1}$ of blood (Sehgal et al. 1989; McGuinness et al. 1998; Afolabi et al. 2001; Falade et al. 2007; Mwaniki et al. 2010). Such infections are frequently transient, with spontaneous clearance of parasites occurring more quickly than in older infants and children, suggesting that young infants possess some mechanisms for controlling and clearing parasitaemia (Kitua et al. 1996; McGuinness et al. 1998; Franks et al. 2001; Falade et al. 2007). Young infants are less likely to be febrile with Pf infection, though the parasite density thresholds for fever appears to be lower in infants (estimated at 100 parasites $\mu \mathrm{L}^{-1}$ ) than in children older than 12 months (3500 parasites $\mu \mathrm{L}^{-1}$ ) (McGuinness et al. 1998). However, very high parasite densities have been detected in afebrile, asymptomatic infants, suggesting that failure to mount a febrile response to Pf infection may be due to a specific mechanism, such as lack of immunologic priming of $\mathrm{T}$ cells needed to produce pro-inflammatory cytokines (McGuinness et al. 1998; Riley, 1999). Clinical manifestations of symptomatic malaria infection in neonates and young infants are non-specific and difficult to distinguish from other diseases, such as bacterial sepsis. Signs and symptoms include fever, anaemia, pallor, splenomegaly, lethargy, poor feeding, diarrhoea, respiratory distress, cyanosis, hepatomegaly, jaundice and seizures (Ibhanesebhor, 1995; Afolabi et al. 2001; Mwaniki et al. 2010).

This relative protection against clinical Pf malaria and progression to severe disease in young infants may be explained by a number of potential immunologic, physiologic and environmental mechanisms. Studies of the biting habits of anopheline mosquitoes show that infants are fed on less frequently than larger adults and older children, which may offer some protection against infection (MuirheadThomson, 1951; Port, 1980). Diet may also play an important role in protection. Breast milk constituents such as lactoferrin and secretory $\operatorname{IgA}$ have been shown to inhibit parasite growth in vitro (Kassim et al. 2000). Parasite replication depends on an external source of the nutrient paraaminobenzoic acid, which is low in breast milk (Kicska et al. 2003). The presence of fetal haemoglobin $(\mathrm{HbF})$ may provide a physiologic mechanism for protection against clinical malaria. Some studies suggest that parasite growth is restricted in erythrocytes containing higher levels of $\mathrm{HbF}$ (Pasvol et al. 1977). A transgenic mouse model of adult persistence of $\mathrm{HbF}$ demonstrated delayed parasite development and protection from severe disease (Shear et al. 1998). In a more recent study, Amaratunga et al. showed that Pf parasites invaded and grew normally in cord blood erythrocytes, but that parasitized cord blood erythrocytes had impaired cytoadherence properties; the presence of immune $\mathrm{IgG}$ further impaired the ability of these parasitized cells to adhere, suggesting that $\mathrm{HbF}$ and maternal $\mathrm{IgG}$ act cooperatively to protect young infants (Amaratunga et al. 2011).

MATERNAL ANTIMALARIAL ANTIBODIES IN THE YOUNG INFANT: ROLE OF PROTECTION OR MARKER OF EXPOSURE?

Transplacental transfer of maternal IgG antibodies to the fetus occurs primarily in the third trimester and is mediated by the neonatal $\mathrm{Fc}$ receptor (Simister, 2003). After birth, maternal antibodies of all isotypes, but primarily $\operatorname{IgA}$, are transferred to infants in breast milk, though these are not systemically absorbed and act primarily in the gut (Van de Perre, 2003). Studies of birth cohorts in sub-Saharan Africa have reported the waning of maternal antimalarial $\mathrm{IgG}$ antibodies by $6-9$ months of age, which coincides with the period of time in which the risk for malaria infection and clinical disease in infants begins to increase (Achidi et al. 1995; Riley et al. 2000; Duah et al. 2010; Kangoye et al. 2014; Nhabomba et al. 2014). It has long been proposed that passive transfer of maternal antimalarial antibodies confers protection against clinical disease in young infants (McGregor et al. 1970; Logie et al. 1973; McGuinness et al. 1998). However, the evidence supporting this assumption is lacking. In Table 1, we summarize the evidence in the literature regarding the question: are maternal antimalarial antibodies that are present at the time of delivery (in maternal and/or cord blood) associated with infant malaria protection? The studies referenced in the table focus on Pf infection.

Longitudinal studies designed to answer this question vary in regards to antigens studied, reported outcomes (infection vs clinical disease), method for 
Table 1. Maternal antibodies and association with protection against Pf malaria in infants ${ }^{\mathrm{a}}$

\begin{tabular}{|c|c|c|c|}
\hline Antigen & Association & $\begin{array}{l}\text { Study } \\
\text { location }\end{array}$ & References \\
\hline & Associated with protection & & \\
\hline \multirow[t]{2}{*}{$\mathrm{MSP}_{19}$} & $\begin{array}{l}\text { Increased duration to first infection (113 vs } 69 \text { days), } \\
\text { detected by microscopy }\end{array}$ & Kenya & $\begin{array}{l}\text { Branch et al. } \\
\text { (1998) }\end{array}$ \\
\hline & $\begin{array}{l}\text { Protection against clinical disease in the first } 12 \\
\text { months of life }\end{array}$ & Liberia & $\begin{array}{l}\text { Hogh et al. } \\
\text { (1995) }\end{array}$ \\
\hline CIDR1 $\alpha$ & $\begin{array}{l}\text { Increased duration to first infection ( } 6 \text { vs } 3 \text { months), } \\
\text { detected by microscopy }\end{array}$ & Senegal & $\begin{array}{l}\text { Khattab et al. } \\
\text { (2007) }\end{array}$ \\
\hline Crude Pf culture antigen & $\begin{array}{l}\text { Seropositivity for anti-Pf IgG2 subclass in cord } \\
\text { blood associated with protection against infection } \\
\text { in first } 6 \text { months of life, detected by microscopy (no } \\
\text { association seen with anti-Pf IgG1, IgG3 or IgG4) }\end{array}$ & Cameroon & $\begin{array}{l}\text { Deloron et al. } \\
\text { (1997) }\end{array}$ \\
\hline $\begin{array}{l}\text { CSP, MSP1 } 19, \text { MSP2-FC27, } \\
\text { Pf155/RESA and crude schiz- } \\
\text { ont antigen }\end{array}$ & $\begin{array}{l}\text { Associated with higher risk } \\
\text { Increased risk of infection in first } 5 \text { months of life, } \\
\text { detected by PCR }\end{array}$ & Ghana & Riley et al. (2000) \\
\hline MSP-3 & $\begin{array}{l}\text { Increased risk of febrile malaria in first } 24 \text { months of } \\
\text { life }\end{array}$ & $\begin{array}{l}\text { Burkina } \\
\text { Faso }\end{array}$ & $\begin{array}{l}\text { Kangoye et al. } \\
\text { (2014) }\end{array}$ \\
\hline \multirow[t]{2}{*}{ CSA-VSA } & $\begin{array}{l}\text { Decreased time to first parasitaemia and with higher } \\
\text { parasite density, detected by microscopy }\end{array}$ & Cameroon & Cot et al. (2003) \\
\hline & No association & & \\
\hline Sporozoites & $\begin{array}{l}\text { No association with time to first infection, detected } \\
\text { by microscopy }\end{array}$ & Tanzania & $\begin{array}{l}\text { Mutabingwa } \\
\text { et al. (1993) }\end{array}$ \\
\hline CSP, LSA1, MSP2 & $\begin{array}{l}\text { No association with time to first infection, detected } \\
\text { by microscopy }\end{array}$ & Kenya & Zhou et al. (2002) \\
\hline AMA1, MSP2-IC1 & $\begin{array}{l}\text { No association with risk of infection in first } 5 \\
\text { months of life, detected by PCR }\end{array}$ & Ghana & Riley et al. (2000) \\
\hline CSP, Pf155/RESA & No association with age of onset of clinical malaria & Nigeria & $\begin{array}{l}\text { Achidi et al. } \\
\text { (1996) }\end{array}$ \\
\hline Pf155/RESA & $\begin{array}{l}\text { No association with risk of infection in first } 6 \\
\text { months of life, detected by microscopy }\end{array}$ & Cameroon & $\begin{array}{l}\text { Deloron et al. } \\
\text { (1997) }\end{array}$ \\
\hline GLURP & $\begin{array}{l}\text { No association with risk of febrile malaria in first } 24 \\
\text { months of life }\end{array}$ & $\begin{array}{l}\text { Burkina } \\
\text { Faso }\end{array}$ & $\begin{array}{l}\text { Kangoye et al. } \\
\text { (2014) }\end{array}$ \\
\hline Crude schizont antigen & $\begin{array}{l}\text { No association with risk of clinical disease in first } 12 \\
\text { months of life in multivariate analysis }\end{array}$ & Cameroon & $\begin{array}{l}\text { Apinjoh et al. } \\
\text { (2015) }\end{array}$ \\
\hline
\end{tabular}

a Maternal antibodies are defined as antimalarial antibodies present at the time of birth in either maternal or cord blood. CSP, circumsporozoite protein; MSP1 ${ }_{19}$, merozoite surface protein-1 GPI-anchored 19-kD fragment; CIDR1 $\alpha$, cysteinerich interdomain region of $P$. falciparum 732var gene; Pf155/RESA, ring-infected erythrocyte surface antigen; MSP2FC27, merozoite surface protein-2 from FC27 P. falciparum isolate; MSP3, merozoite surface protein-3; CSA-VSA, chondroitin sulphate-A variant surface antigen; LSA1, liver stage antigen-1; AMA1, apical membrane antigen-1; MSP2-IC1, merozoite surface protein-2 from IC1 P. falciparum isolate; GLURP, glutamate-rich protein.

detecting parasitaemia, location and transmission intensity. A few of these studies have demonstrated an association between maternal antimalarial antibodies and protection from infection (Deloron et al. 1997; Khattab et al. 2007), clinical disease (Hogh et al. 1995) or both (Branch et al. 1998) in infants. However, several others have found an association between maternal antibodies and an increased risk for infection in infants (Riley et al. 2000; Cot et al. 2003; Kangoye et al. 2014), or no association at all (Mutabingwa et al. 1993; Achidi et al. 1996; Deloron et al. 1997; Riley et al. 2000; Zhou et al. 2002; Kangoye et al. 2014; Apinjoh et al. 2015). For example, the presence of maternal antibodies against merozoite invasion protein 1 (MSP1 19$)$ were associated with delayed onset of first infection among a cohort in western Kenya and with protection of infants against clinical disease in Liberia (Gottschau and Hogh, 1995; Branch et al. 1998). In a comprehensive study of the role of passively acquired antimalarial antibodies in infants living in Southern Ghana, Riley et al. found that antibodies against MSP1 19 (as well as circumsporozoite surface protein (CSP), MSP2, ring-infected erythrocyte surface antigen (Pf155/RESA) and crude schizont antigen) were positively associated with infection (Riley et al. 2000). Other studies in West Africa also found a positive association between maternal antibodies against MSP3 and chondroitin sulphate A (CSA)-VSA and an increased risk for malaria (Cot et al. 2003; Kangoye et al. 2014). We and these authors conclude that the presence of antimalarial antibodies at birth is a biomarker for intensity of exposure to malaria in infants (Franks et al. 2001).

It is important to consider that different antigens have been used as markers of Pf infection so there 
is very little consistency between studies. In a study of malaria-exposed pregnant women in Senegal, Khattab et al. showed that maternal antibodies against the 732var Pf erythrocyte membrane protein 1 (PfEMP1) domain cysteine-rich interdomain region $1 \alpha(\mathrm{CIDR} 1 \alpha)$ conferred protection against malaria in infants during the first 6 months of life (Khattab et al. 2007). In another study of anti-VSA antibodies, Cot et al. showed that the presence of maternal antibodies against CSA-VSA was associated with a decreased time to first parasitaemia (Cot et al. 2003). These discrepant results are likely explained by the different function of the antigens. CIDR1 $\alpha$ mediates parasite sequestration by binding to endothelial cell surface receptors, and this domain is expressed in parasite strains relevant to infection and disease in young children (Avril et al. 2013; Turner et al. 2013; Smith, 2014). Antibodies directed against CSA-VSA are important in response to placental malaria, and thus likely represent recent exposure in mothers of these infants.

Several factors contribute to an infant's risk for malaria, and it is difficult to disentangle any one factor from the others. The waning of maternal antibodies occurs simultaneously with the waning of $\mathrm{HbF}$, changes in infants' diets, and decreased breastfeeding, all of which might alter risk for malaria (Colombo et al. 1976). Transmission intensity and season of birth have been shown to be very important factors in risk for clinical disease (Riley et al. 2000; Apinjoh et al. 2015). Maternal HIV and placental malaria have also been implicated (Briand et al. 2009).

PLASMODIUMVIVAX (PV) INFECTION IN THE NEONATE AND INFANT

Cases of congenital $\mathrm{Pv}$ malaria have been described in infants born to mothers without pre-existing antimalarial immunity, mostly in case reports of infants born in non-endemic countries to mothers with a travel history to endemic countries (Del Punta et al. 2010). These infants often present several days to weeks after birth with fever, irritability and hepatosplenomegaly, and if untreated, the infection may be rapidly fatal (Menendez and Mayor, 2007). Very little is known about the development of humoral immunity to $\mathrm{Pv}_{\mathrm{v}}$ in the first year of life. The majority of $\mathrm{Pv}$ infections occur in Southeast Asia and the Western Pacific, with a significant number of cases also occurring in the Eastern Mediterranean, South and Central America, and Africa (Price et al. 2007). Studies performed in Papua New Guinea, Indonesia and Vanuatu demonstrate that in areas endemic for both $\mathrm{Pv}$ and $\mathrm{Pf}, \mathrm{Pv}$ serves as the predominant cause of malaria infection during the first 2 years of life (Maitland et al. 1996; Karyana et al. 2008; Poespoprodjo et al. 2009; Senn et al. 2012). In contrast to Pf infection in young infants, which has a low risk for progression to symptomatic or severe disease, $\mathrm{Pv}_{\mathrm{v}}$ infection in infants younger than 3 months of age is a significant cause of morbidity in endemic areas, characterized by higher parasite densities and substantial risk for development of severe disease (Poespoprodjo et al. 2009). Limited data exist regarding risk factors for $\mathrm{Pv}$ malaria in infants, and as with Pf, it is not known if transfer of maternal antimalarial antibodies confers any protection against $\mathrm{Pv}$ infection in infants (Campbell et al. 1980). Clinical immunity to $\mathrm{Pv}$ appears to develop more rapidly than to Pf, with most children in endemic areas acquiring immunity to $\mathrm{Pv}$ by 5 years of age while remaining at risk for $\mathrm{Pf}$ illness (Michon et al. 2007). Further studies are needed to evaluate how protective immunity develops in infants and to determine which factors might be unique to $\mathrm{Pv}$ compared with $\mathrm{Pf}$ infant infections.

PREGNANCY-ASSOCIATED PF MALARIA AND INFANT IMMUNITY

Pregnancy-associated malaria (either peripheral or placental detection of parasites) can have devastating effects on both mother and fetus, including anaemia, stillbirth, low birthweight, intrauterine growth retardation and pre-term delivery (Brabin, 1991; Menendez, 1995; Brabin et al. 2004; Nosten et al. 2004; Desai et al. 2007; Rogerson et al. 2007). Some studies have found that infants born to mothers with Pf placental malaria have increased susceptibility to malaria with earlier infections compared with those born to mothers with no evidence of pregnancy-associated malaria (Le Hesran et al. 1997; Mutabingwa et al. 2005; Schwarz et al. 2008; Malhotra et al. 2009; Bardaji et al. 2011; Le Port et al. 2011). The reasons for this are likely multifactorial with maternal parity, receipt of intermittent preventive treatment during pregnancy, use of insecticide treated bed nets and malaria transmission intensity playing important roles (Apinjoh et al. 2015).

In utero exposure to parasite antigens may induce fetal immune tolerance (Le Hesran et al. 1997). In placental malaria, infected erythrocytes sequester in the intervillous blood of the placenta such that the fetus may be exposed to infected erythrocytes or soluble malaria antigens that cross the placenta. May et al. (2009) showed that immune-complexed MSP1 transferred from maternal to fetal circulation using an ex vivo human placental cotyledon model. Numerous studies have shown that fetal cord blood lymphocytes can have recall responses to specific malaria antigens (Fievet et al. 1996; King et al. 2002; Malhotra et al. 2005, 2009, 2015; Dent et al. 2006; Metenou et al. 2007) and cord blood can have fetal malaria-specific IgM and IgE, immunoglobulins that do not cross the placenta (Rasheed 
et al. 1995; Xi et al. 2003; Apinjoh et al. 2015). The consequence of fetal tolerance to malaria antigens is poorly understood, but we have shown that infants exposed to malaria in utero but lacking malariaspecific cord blood lymphocyte recall responses (putatively tolerized) make less functional MSP $1_{19}$ invasion inhibitory antibodies (Dent et al. 2006). Bonner et al. showed that infants born to mothers with placental malaria had lower antibody responses to multiple malaria antigens, including CSP, EBA175 and MSP2 compared with infants born to placental malaria negative mothers. This difference was apparent especially after 4 months of age when maternal antibodies wane (Bonner et al. 2005). Thus, in utero exposure to malaria may have detrimental effects on infant antimalarial antibody generation through poorly understood mechanisms. It is likely, this is a generalizable immune consequence as infants born to mothers with placental malaria have increased all-cause mortality (Verhoeff et al. 2004; Bardaji et al. 2011; Rachas et al. 2012). Additionally, malaria putatively tolerized Kenyan infants, those with in utero exposure to malaria but lacking cord blood lymphocyte recall responses to malaria antigens, had lower levels of antibodies to diphtheria toxin vaccine compared with those infants who were not exposed to malaria in utero (Malhotra et al. 2015). Thus, fetal exposure to malaria in utero may affect subsequent infant immune responses to malaria and other pathogens.

ACQUISITION OF ANTIMALARIAL ANTIBODIES IN THE INFANT AFTER 6 MONTHS OF AGE

After maternal antibodies wane, infants exposed to malaria gradually acquire antimalarial antibodies. Evaluation of infant antibody responses to Pf has relied primarily on serologic assays with Pf schizont extract, single recombinant proteins and/or protein domains. Numerous antigens on the surface and within merozoites have been identified as important targets of naturally acquired immunity. Targets include MSPs thought to be important in initial attachment of the merozoite to the erythrocyte, apical membrane antigen (AMA1) implicated in apical reorientation of merozoite, and erythrocytebinding proteins (e.g. EBA175, EBA140 and EBA181) and reticulocyte-binding homologues (e.g. Rh4 and Rh5) thought to be important in erythrocyte invasion (Cowman and Crabb, 2006). Pre-erythrocytic antigens such as CSP are also important targets as infant trials with the vaccine containing CSP named 'RTS,S' have indicated (Rts, 2015). Studies of antimalarial antibodies and protection from malaria in children vary greatly in design, outcome measured (i.e. infection or symptomatic disease), age of children included, transmission intensity and duration of follow-up. Alleles and recombinant protein preparation used also vary widely. A challenge to this review is the paucity of studies conducted in infants. Thus, we extended our review of the literature to include studies that included 12-month-old infants and young children. In multiple studies including infants and young children, serologically measured antibodies against targets such as MSP1, MSP2, MSP3, AMA1, glutamate-rich protein (GLURP) and EBA175 have been associated with protection from clinical malaria (Roussilhon et al. 2007; Osier et al. 2008; Fowkes et al. 2010; Richards et al. 2010, 2013). With recent advances in genomics, proteomics and methods for protein expression, an increasing number of putative targets of naturally acquired immunity are being identified. These include hypothetical proteins and targets with no identified function. Osier et al. examined antibodies to 36 different proteins in a cohort of Kenyan children who were followed for malaria for 6 months. They found that the breadth and magnitude of antibody responses increased with age, and that the breadth of responses was a better correlate of protection than individual antibody responses (Osier et al. 2008). In our microarray study examining antibody responses in a treatment-time to infection study in Kenya, we also found that 1-4-year-old children had the narrowest breadth and the lowest magnitude of antibody responses compared with older children and adults (Dent et al. 2015). In our longitudinal infant study in Kenya, 12-month-old infants who had detectable serologically measured antimalarial antibodies had an increased risk of malaria in the subsequent year of life compared with 12-monthold infants with no detectable antimalarial antibodies (Dent submitted). Recently, Stanisic et al. (2015) examined antimalarial antibodies in cohorts of 1-4 and 5-14-year-old Papua New Guinean children. They found that young children who had higher levels of antibodies to MSP2, AMA1, EBA175, EBA140 and EBA181 had an increased risk of malaria compared with young children with low or no detectable antimalarial antibodies. Additionally, young children had antimalarial antibodies that were of significantly lower magnitude than those found in protected older (5-14-year-old) children. Results of this study indicate that one of the reasons why antibody responses in young infants represent biomarkers of malaria exposure rather than protection from malaria is related to failure of antibody responses to reach a critical 'protective' level, as determined by serology, until age 4 years or older. This is consistent with other studies that have found the magnitude of antibody responses influences protection from malaria (John et al. 2005; Osier et al. 2008; Courtin et al. 2009; Murungi et al. 2013). Serologically measured antimalarial antibodies may be a biomarker of exposure rather than protection especially in infants. Serology detects the presence of antibodies recognizing an antigen, 
but does not measure the function of these antibodies. Despite this, serology is useful to identify and prioritize antigen targets, especially in older protected children and adults, which may be valuable in a multicomponent vaccine, essential for eradicating malaria. Follow-up functional assays are invaluable tools in validating serologically identified targets.

VSAs are considered a major target of naturally acquired immunity (Bull et al. 1998; Hviid, 2010; Chan et al. 2014) and include PfEMP1, repetitive interspersed family, subtelomeric variable open reading frame and surface-associated interspersed gene family proteins with PfEMP1 being the key target of humoral immunity (Chan et al. 2012). PfEMP1, encoded by the var multigene family, is highly polymorphic and expression is clonally variant (Smith et al. 1995). Antibodies that bind to VSA may function to prevent tissue sequestration by blocking VSA binding to endothelial receptors and facilitating opsonic phagocytosis by monocytes and macrophages. Serology has been used to measure antibody responses to various proteins and protein domains, but the VSA assay utilizes the whole Pf parasite to identify IgG antibodies that recognize the trafficked proteins on the surface of the infected erythrocyte. VSA antibodies are known to be highly parasite isolate-specific among children (Marsh and Howard, 1986; Reeder et al. 1994), and may be short-lived (Kinyanjui et al. 2003). It is thought that young children develop VSA antibodies to parasites expressing VSA associated with severe disease earlier in childhood than VSA associated with mild or moderate disease (Hviid and Staalsoe, 2004). Studies in infants are limited but Vestergaard et al. (2008) showed that infants residing in a low malaria transmission region of Tanzania had low prevalence and magnitude of VSA antibodies compared with infants residing in regions of high transmission. In high transmission areas, VSA antibodies increased with age between 5 and 24 months. Nhabomba et al. (2014) found a lack of VSA antibody acquisition in infants up to 2 years of age in Mozambique, though their group previously found that infants acquire VSA antibodies in a study conducted in the same region at an earlier time when malaria transmission was presumably higher (Quelhas et al. 2011). A caveat to these observations is that the parasite isolates used in these studies may not accurately represent the circulating parasites at the time the studies were conducted. A study in Papua New Guinea using a PfEMP1 microarray demonstrated that young children ( $<2$ years old) had low prevalence, magnitude and breadth of antibodies compared with older children (Barry et al. 2011). In general, VSA antibodies are low in infants and may not be readily acquired in the first year of life depending in large part on the geographical malaria transmission levels.
A better way to evaluate infant immunity may be to use assays that assess the function of the antimalarial antibodies. Antibodies may function by binding to merozoite surface proteins to inhibit erythrocyte invasion and intraerythrocytic growth. These can be measured with the Growth Inhibition Assay (GIA) which quantifies antibodymediated activity against parasites in vitro and has been used to assess vaccine efficacy in animal models and malaria-naïve human volunteers (Singh et al. 2006; Dutta et al. 2009; Spring et al. 2009; Remarque et al. 2012; Otsyula et al. 2013). In malaria endemic populations, naturally acquired immunity measured by GIA has been associated with protection from infection in children in some studies, but this has not been a consistent finding (Dent et al. 2008; McCallum et al. 2008; Courtin et al. 2009; Crompton et al. 2010). Growth inhibitory activity appears to decrease or remain relatively stable with age (Dent et al. 2008; McCallum et al. 2008; Courtin et al. 2009). Few studies have examined GIA in infants specifically. Wilson et al. examined GIA in infants from delivery to 12 months of age and found that GIA antibodies decline over time becoming essentially undetectable by 12 months of age (Wilson et al. 2013). In contrast, Quelhas et al. found detectable GIA in 12-monthold infants that increased by 24 months of age but was not associated with protection from malaria (Quelhas et al. 2011). In a longitudinal Kenyan infant study utilizing the MSP1 19 mediated invasion inhibition assay (MSP1 19 IIA) which uses transgenic parasites, by 12 months of age, infants had detectable MSP1 $_{19}$ IIA that gradually increased by 24-30 months after birth (Dent et al. 2006). The MSP1 19 IIA measures one pathway of invasion inhibition which is only one component of the overall GIA. A drawback of GIA is that the targets of the antibodies that inhibit growth in vitro are not known and as with the VSA assay, the parasite isolates used in the GIA may not accurately represent the circulating parasites. Young children may have GIA antibodies, but this may be a reflection of malaria transmission (McCallum et al. 2008). Further studies of the acquisition of functional antibodies in young children are needed.

In summary, infants acquire antimalarial antibodies with serologically measurable antibodies possibly acquired earlier than VSA or GIA measured antibodies which may reflect the late and complex acquisition of functional antibodies. Serologically measured antibodies may be a biomarker of exposure and may not protect the young child until a certain magnitude threshold is reached. These observations coupled with the immaturity of the infant immune system until 2 years of age (Jaspan et al. 2006) makes understanding how infants and young children acquire immunity a challenge. 


\section{Concluding remarks and future directions}

Early infancy is a critical time in the development of immunity to malaria in children born in malaria endemic areas. Antibodies are known to play an important role in host defence against malaria, but the acquisition of antimalarial humoral immunity in infants is not yet well understood. Passively transferred maternal antibodies thought to protect infants younger than 6 months from clinical disease may actually be a biomarker of exposure and risk of infection rather than a correlate of protection. Infants with maternal antimalarial antibodies still become infected with low-grade parasite densities. As maternal antibodies wane, older infants gradually acquire antimalarial antibodies, with increasing breadth and magnitude of responses with age and exposure. Fetal exposure to malaria in utero may have an important effect on infant immune responses to malaria and other pathogens. In infants and young children, antibodies detected by serology may be a biomarker of exposure, with protection afforded only after a critical threshold is reached. As infants are a target population for future malaria vaccines, understanding the complexity of achieving protection in the context of an immature immune system must be considered. Further studies and development of novel assays are needed to analyse the functional capabilities of these antibodies and to evaluate the maternal, fetal and neonatal factors leading to the development of protective immunity in infants.

\section{ACKNOWLEDGMENTS}

We would like to acknowledge the important contributions made to this work by our colleagues at the Kenya Medical Research Institute and Case Western Reserve University.

\section{FINANCIAL SUPPORT}

This work was supported by the National Institutes of Health (grant AI098511 to A.E.D.)

\section{REFERENCES}

Achidi, E. A., Perlmann, H., Salimonu, L. S., Perlmann, P., Walker, O. and Asuzu, M. C. (1995). A longitudinal study of seroreactivities to Plasmodium falciparum antigens in Nigerian infants during their first year of life. Acta Tropica 59, 173-183.

Achidi, E. A., Salimonu, L. S., Perlmann, H., Perlmann, P., Berzins, K. and Williams, A. I. (1996). Lack of association between levels of transplacentally acquired Plasmodium falciparum-specific antibodies and age of onset of clinical malaria in infants in a malaria endemic area of Nigeria. Acta Tropica 61, 315-326.

Afolabi, B. M., Salako, L. A., Mafe, A. G., Ovwigho, U. B., Rabiu, K. A., Sanyaolu, N. O. and Ibrahim, M. M. (2001). Malaria in the first 6 months of life in urban African infants with anemia. American fournal of Tropical Medicine and Hygiene 65, 822-827.

Amaratunga, C., Lopera-Mesa, T. M., Brittain, N. J., Cholera, R., Arie, T., Fujioka, H., Keefer, J. R. and Fairhurst, R. M. (2011). A role for fetal hemoglobin and maternal immune $\operatorname{IgG}$ in infant resistance to Plasmodium falciparum malaria. PLoS ONE 6, e14798.
Apinjoh, T. O., Anchang-Kimbi, J. K., Mugri, R. N., Njua-Yafi, C., Tata, R. B., Chi, H. F., Tangoh, D. A., Loh, B. T. and Achidi, E. A. (2015). Determinants of infant susceptibility to malaria during the first year of life in South Western Cameroon. Open Forum Infectious Diseases 2, ofv012.

Avril, M., Brazier, A. J., Melcher, M., Sampath, S. and Smith, J. D. (2013). DC8 and DC13 var genes associated with severe malaria bind avidly to diverse endothelial cells. PLoS Pathogens 9, e1003430.

Bardaji, A., Sigauque, B., Sanz, S., Maixenchs, M., Ordi, J., Aponte, J. J., Mabunda, S., Alonso, P. L. and Menendez, C. (2011). Impact of malaria at the end of pregnancy on infant mortality and morbidity. The Fournal of Infectious Diseases 203, 691-699.

Barry, A. E., Trieu, A., Fowkes, F. J., Pablo, J., KalantariDehaghi, M., Jasinskas, A., Tan, X., Kayala, M. A., Tavul, L., Siba, P. M., Day, K. P., Baldi, P., Felgner, P. L. and Doolan, D. L. (2011). The stability and complexity of antibody responses to the major surface antigen of Plasmodium falciparum are associated with age in a malaria endemic area. Molecular and Cellular Proteomics 10, M111 008326. Bonner, P. C., Zhou, Z., Mirel, L. B., Ayisi, J. G., Shi, Y.P., van Eijk, A.M., Otieno, J.A., Nahlen, B. L., Steketee, R.W. and Udhayakumar, V. (2005). Placental malaria diminishes development of antibody responses to Plasmodium falciparum epitopes in infants residing in an area of western Kenya where P. falciparum is endemic. Clinical and Diagnostic Laboratory Immunology 12, 375-379.

Brabin, B. (1991). An assessment of low birthweight risk in primiparae as an indicator of malaria control in pregnancy. International fournal of Epidemiology 20, 276-283.

Brabin, B. J., Romagosa, C., Abdelgalil, S., Menendez, C., Verhoeff, F.H., McGready, R., Fletcher, K. A., Owens, S., D'Alessandro, U., Nosten, F., Fischer, P. R. and Ordi, J. (2004). The sick placenta-the role of malaria. Placenta 25, 359-378.

Branch, O.H., Udhayakumar, V., Hightower, A. W., Oloo, A. J., Hawley, W. A., Nahlen, B.L., Bloland, P. B., Kaslow, D. C. and Lal, A. A. (1998). A longitudinal investigation of IgG and IgM antibody responses to the merozoite surface protein-1 19-kiloDalton domain of Plasmodium falciparum in pregnant women and infants: associations with febrile illness, parasitemia, and anemia. American fournal of Tropical Medicine and Hygiene 58, 211-219.

Briand, V., Badaut, C. and Cot, M. (2009). Placental malaria, maternal HIV infection and infant morbidity. Annals of Tropical Paediatrics 29 , 71-83.

Bruce-Chwatt, L. J. (1952). Malaria in African infants and children in Southern Nigeria. Annals of Tropical Medicine Parasitology 46, 173-200.

Bull, P. C., Lowe, B. S., Kortok, M., Molyneux, C. S., Newbold, C. I. and Marsh, K. (1998). Parasite antigens on the infected red cell surface are targets for naturally acquired immunity to malaria. Nature Medicine 4, 358-360.

Campbell, C. C., Martinez, J.M. and Collins, W. E. (1980). Seroepidemiological studies of malaria in pregnant women and newborns from coastal El Salvador. American Fournal of Tropical Medicine and Hygiene 29, 151-157.

Chan, J. A., Howell, K. B., Reiling, L., Ataide, R., Mackintosh, C. L., Fowkes, F. J., Petter, M., Chesson, J. M., Langer, C., Warimwe, G. M., Duffy, M. F., Rogerson, S. J., Bull, P. C., Cowman, A. F., Marsh, K. and Beeson, J. G. (2012). Targets of antibodies against Plasmodium falciparum-infected erythrocytes in malaria immunity. The 7ournal of Clinical Investigation 122, 3227-3238.

Chan, J. A., Fowkes, F. J. and Beeson, J. G. (2014). Surface antigens of Plasmodium falciparum-infected erythrocytes as immune targets and malaria vaccine candidates. Cellular and Molecular Life Sciences 71, 3633-3657.

Cohen, S., Mc, G. I. and Carrington, S. (1961). Gamma-globulin and acquired immunity to human malaria. Nature 192, 733-737.

Colombo, B., Kim, B., Atencio, R. P., Molina, C. and Terrenato, L. (1976). The pattern of fetal haemoglobin disappearance after birth. British Fournal of Haematology 32, 79-87.

Cot, M., Le Hesran, J. Y., Staalsoe, T., Fievet, N., Hviid, L. and Deloron, P. (2003). Maternally transmitted antibodies to pregnancy-associated variant antigens on the surface of erythrocytes infected with Plasmodium falciparum: relation to child susceptibility to malaria. American Fournal of Epidemiology 157, 203-209.

Courtin, D., Oesterholt, M., Huismans, H., Kusi, K., Milet, J., Badaut, C., Gaye, O., Roeffen, W., Remarque, E. J., Sauerwein, R., Garcia, A. and Luty, A. J. (2009). The quantity and quality of African children's IgG responses to merozoite surface antigens reflect protection against Plasmodium falciparum malaria. PLoS ONE 4, e7590.

Covell, G. (1950). Congenital malaria. Tropical Diseases Bulletin 47, 1147-1167. 
Cowman, A.F. and Crabb, B. S. (2006). Invasion of red blood cells by malaria parasites. Cell 124, 755-766.

Crompton, P. D., Miura, K., Traore, B., Kayentao, K., Ongoiba, A. Weiss, G., Doumbo, S., Doumtabe, D., Kone, Y., Huang, C. Y., Doumbo, O. K., Miller, L. H., Long, C. A. and Pierce, S. K. (2010). In vitro growth-inhibitory activity and malaria risk in a cohort study in mali. Infection and Immunity 78, 737-745.

Deloron, P., Dubois, B., Le Hesran, J.Y., Riche, D., Fievet, N., Cornet, M., Ringwald, P. and Cot, M. (1997). Isotypic analysis of maternally transmitted Plasmodium falciparum-specific antibodies in Cameroon, and relationship with risk of $P$. falciparum infection. Clinical and Experimental Immunology 110, 212-218.

Del Punta, V., Gulletta, M., Matteelli, A., Spinoni, V., Regazzoli, A. and Castelli, F. (2010). Congenital Plasmodium vivax malaria mimicking neonatal sepsis: a case report. Malaria fournal 9, 63.

Dent, A., Malhotra, I., Mungai, P., Muchiri, E., Crabb, B.S. Kazura, J. W. and King, C. L. (2006). Prenatal malaria immune experience affects acquisition of Plasmodium falciparum merozoite surface protein-1 invasion inhibitory antibodies during infancy. Fournal of Immunology 177, 7139-7145.

Dent, A. E., Bergmann-Leitner, E.S., Wilson, D. W., Tisch, D. J. Kimmel, R., Vulule, J., Sumba, P. O., Beeson, J. G., Angov, E., Moormann, A. M. and Kazura, J. W. (2008). Antibody-mediated growth inhibition of Plasmodium falciparum: relationship to age and protection from parasitemia in Kenyan children and adults. PLoS ONE 3 e3557.

Dent, A. E., Nakajima, R., Liang, L., Baum, E., Moormann, A. M. Sumba, P. O., Vulule, J., Babineau, D., Davies, D. H., Felgner, P. L. and Kazura, J. W. (2015). Plasmodium falciparum protein microarray antibody profiles correlate with protection from symptomatic malaria in Kenya. The Fournal Infectious Diseases 212, 1429-1438.

Desai, M., ter Kuile, F. O., Nosten, F., McGready, R., Asamoa, K., Brabin, B. and Newman, R.D. (2007). Epidemiology and burden of malaria in pregnancy. The Lancet Infectious Diseases 7, 93-104.

Duah, N. O., Miles, D. J., Whittle, H. C. and Conway, D. J. (2010). Acquisition of antibody isotypes against Plasmodium falciparum blood stage antigens in a birth cohort. Parasite Immunology 32, 125-134.

Dups, J. N., Pepper, M. and Cockburn, I. A. (2014). Antibody and B cell responses to Plasmodium sporozoites. Frontiers in Microbiology 5, 625. Dutta, S., Sullivan, J.S., Grady, K. K., Haynes, J.D., Komisar, J., Batchelor, A.H., Soisson, L., Diggs, C. L., Heppner, D. G., Lanar, D. E., Collins, W. E. and Barnwell, J. W. (2009). High antibody titer against apical membrane antigen-1 is required to protect against malaria in the Aotus model. PLoS ONE 4, e8138.

Falade, C., Mokuolu, O., Okafor, H., Orogade, A., Falade, A., Adedoyin, O., Oguonu, T., Aisha, M., Hamer, D.H. and Callahan, M. V. (2007). Epidemiology of congenital malaria in Nigeria: a multi-centre study. Tropical Medicine and International Health 12 , 1279-1287.

Fievet, N., Ringwald, P., Bickii, J., Dubois, B., Maubert, B., Le Hesran, J.Y., Cot, M. and Deloron, P. (1996). Malaria cellular immune responses in neonates from Cameroon. Parasite Immunology $\mathbf{1 8}$ 483-490.

Fowkes, F. J., Richards, J. S., Simpson, J. A. and Beeson, J. G. (2010). The relationship between anti-merozoite antibodies and incidence of Plasmodium falciparum malaria: a systematic review and meta-analysis. PLoS Medicine 7, e1000218.

Franks, S., Koram, K. A., Wagner, G. E., Tetteh, K., McGuinness, D., Wheeler, J. G., Nkrumah, F., Ranford-Cartwright, L. and Riley, E. M. (2001). Frequent and persistent, asymptomatic Plasmodium falciparum infections in African infants, characterized by multilocus genotyping. The Fournal of Infectious Diseases 183, 796-804.

Gottschau, A. and Hogh, B. (1995). Interval censored survival data and multistate compartmental models in the analysis of first appearance of Plasmodium falciparum parasites in infants. Statistics in Medicine 14, 2727-2736.

Hill, D. L., Eriksson, E.M., Li Wai Suen, C.S., Chiu, C. Y., RygCornejo, V., Robinson, L. J., Siba, P. M., Mueller, I., Hansen, D.S. and Schofield, L. (2013). Opsonising antibodies to P. falciparum merozoites associated with immunity to clinical malaria. PLoS ONE 8, e74627.

Hogh, B., Marbiah, N. T., Burghaus, P. A. and Andersen, P. K. (1995). Relationship between maternally derived anti-Plasmodium falciparum antibodies and risk of infection and disease in infants living in an area of Liberia, West Africa, in which malaria is highly endemic. Infection and Immunity 63, 4034-4038.

Hviid, L. (2010). The role of Plasmodium falciparum variant surface antigens in protective immunity and vaccine development. Human Vaccines $\mathbf{6}$, 84-89.
Hviid, L. and Staalsoe, T. (2004). Malaria immunity in infants: a special case of a general phenomenon? Trends in Parasitology 20, 66-72.

Ibhanesebhor, S. E. (1995). Clinical characteristics of neonatal malaria. Fournal of Tropical Pediatrics 41, 330-333.

Jaspan, H. B., Lawn, S. D., Safrit, J. T. and Bekker, L. G. (2006). The maturing immune system: implications for development and testing HIV-1 vaccines for children and adolescents. AIDS 20, 483-494.

John, C. C., Moormann, A. M., Pregibon, D. C., Sumba, P. O., McHugh, M. M., Narum, D. L., Lanar, D. E., Schluchter, M. D. and Kazura, J. W. (2005). Correlation of high levels of antibodies to multiple pre-erythrocytic Plasmodium falciparum antigens and protection from infection. American Fournal of Tropical Medicine and Hygiene 73, 222-228. Kangoye, D. T., Nebie, I., Yaro, J. B., Debe, S., Traore, S., Ouedraogo, O., Sanou, G., Soulama, I., Diarra, A., Tiono, A., Marsh, K., Sirima, S. B. and Bejon, P. (2014). Plasmodium falciparum malaria in children aged $0-2$ years: the role of foetal haemoglobin and maternal antibodies to two asexual malaria vaccine candidates (MSP3 and GLURP). PLoS ONE 9, e107965.

Karyana, M., Burdarm, L., Yeung, S., Kenangalem, E., Wariker, N. Maristela, R., Umana, K. G., Vemuri, R., Okoseray, M. J., Penttinen, P. M., Ebsworth, P., Sugiarto, P., Anstey, N. M., Tjitra, E. and Price, R. N. (2008). Malaria morbidity in Papua Indonesia, an area with multidrug resistant Plasmodium vivax and Plasmodium falciparum. Malaria fournal 7, 148.

Kassim, O. O., Ako-Anai, K. A., Torimiro, S. E., Hollowell, G.P., Okoye, V. C. and Martin, S. K. (2000). Inhibitory factors in breastmilk, maternal and infant sera against in vitro growth of Plasmodium falciparum malaria parasite. Fournal of Tropical Pediatrics 46, 92-96.

Khattab, A., Chia, Y.S., May, J., Le Hesran, J. Y., Deloron, P. and Klinkert, M. Q. (2007). The impact of IgG antibodies to recombinant Plasmodium falciparum 732var CIDR-1alpha domain in mothers and their newborn babies. Parasitology Research 101, 767-774.

Kicska, G. A., Ting, L. M., Schramm, V. L. and Kim, K. (2003). Effect of dietary $\mathrm{p}$-aminobenzoic acid on murine Plasmodium yoelii infection. The Fournal of Infectious Diseases 188, 1776-1781.

King, C. L., Malhotra, I., Wamachi, A., Kioko, J., Mungai, P., Wahab, S. A., Koech, D., Zimmerman, P., Ouma, J. and Kazura, J. W. (2002). Acquired immune responses to Plasmodium falciparum merozoite surface protein-1 in the human fetus. Fournal of Immunology 168, 356-364.

Kinyanjui, S. M., Bull, P., Newbold, C.I. and Marsh, K. (2003). Kinetics of antibody responses to Plasmodium falciparum-infected erythrocyte variant surface antigens. The Fournal of Infectious Diseases 187, $667-674$.

Kitua, A.Y., Smith, T., Alonso, P.L., Masanja, H., Urassa, H., Menendez, C., Kimario, J. and Tanner, M. (1996). Plasmodium falciparum malaria in the first year of life in an area of intense and perennial transmission. Tropical Medicine and International Health 1, 475-484.

Le Hesran, J.Y., Cot, M., Personne, P., Fievet, N., Dubois, B., Beyeme, M., Boudin, C. and Deloron, P. (1997). Maternal placental infection with Plasmodium falciparum and malaria morbidity during the first 2 years of life. American Fournal of Epidemiology 146, 826-831.

Le Port, A., Watier, L., Cottrell, G., Ouedraogo, S., Dechavanne, C., Pierrat, C., Rachas, A., Bouscaillou, J., Bouraima, A., Massougbodji, A., Fayomi, B., Thiebaut, A., Chandre, F., MigotNabias, F., Martin-Prevel, Y., Garcia, A. and Cot, M. (2011). Infections in infants during the first 12 months of life: role of placental malaria and environmental factors. PLoS ONE 6, e27516.

Logie, D. E., McGregor, I. A., Rowe, D.S. and Billewicz, W.Z. (1973). Plasma immunoglobulin concentrations in mothers and newborn children with special reference to placental malaria: studies in the Gambia, Nigeria, and Switzerland. Bulletin of the World Health Organization 49, 547-554.

Maitland, K., Williams, T. N., Bennett, S., Newbold, C. I., Peto, T. E., Viji, J., Timothy, R., Clegg, J. B., Weatherall, D. J. and Bowden, D. K. (1996). The interaction between Plasmodium falciparum and P. vivax in children on Espiritu Santo island, Vanuatu. Transactions of the Royal Society of Tropical Medicine and Hygiene 90, 614-620.

Malhotra, I., Mungai, P., Muchiri, E., Ouma, J., Sharma, S., Kazura, J. W. and King, C. L. (2005). Distinct Th1 - and Th2-Type prenatal cytokine responses to Plasmodium falciparum erythrocyte invasion ligands. Infection and Immunity 73, 3462-3470.

Malhotra, I., Mungai, P., Muchiri, E., Kwiek, J. J., Meshnick, S. R. and King, C. L. (2006). Umbilical cord-blood infections with Plasmodium falciparum malaria are acquired antenatally in Kenya. The Fournal of Infectious Diseases 194, 176-183.

Malhotra, I., Dent, A., Mungai, P., Wamachi, A., Ouma, J.H., Narum, D. L., Muchiri, E., Tisch, D. J. and King, C. L. (2009). Can 
prenatal malaria exposure produce an immune tolerant phenotype? A prospective birth cohort study in Kenya. PLoS Medicine 6, e1000116.

Malhotra, I., McKibben, M., Mungai, P., McKibben, E., Wang, X., Sutherland, L. J., Muchiri, E. M., King, C. H., King, C. L. and LaBeaud, A. D. (2015). Effect of antenatal parasitic infections on antivaccine IgG levels in children: a prospective birth cohort study in Kenya. PLoS Neglected Tropical Diseases 9, e0003466.

Marsh, K. and Howard, R. J. (1986). Antigens induced on erythrocytes by $P$. falciparum: expression of diverse and conserved determinants. Science 231, 150-153.

May, K., Grube, M., Malhotra, I., Long, C. A., Singh, S., Mandaliya, K., Siegmund, W., Fusch, C., Schneider, H. and King, C. L. (2009). Antibody-dependent transplacental transfer of malaria blood-stage antigen using a human ex vivo placental perfusion model. PLoS ONE 4, e7986.

McCallum, F. J., Persson, K. E., Mugyenyi, C. K., Fowkes, F. J., Simpson, J. A., Richards, J.S., Williams, T. N., Marsh, K. and Beeson, J. G. (2008). Acquisition of growth-inhibitory antibodies against blood-stage Plasmodium falciparum. PLoS ONE 3, e3571.

McGregor, I. A. (1964). The passive transfer of human malarial immunity. American Fournal of Tropical Medicine Hygiene 13(Suppl.), 237-239. McGregor, I. A., Rowe, D.S., Wilson, M.E. and Billewicz, W.Z. (1970). Plasma immunoglobulin concentrations in an African (Gambian) community in relation to season, malaria and other infections and pregnancy. Clinical and Experimental Immunology 7, 51-74.

McGuinness, D., Koram, K., Bennett, S., Wagner, G., Nkrumah, F. and Riley, E. (1998). Clinical case definitions for malaria: clinical malaria associated with very low parasite densities in African infants. Transactions of the Royal Society of Tropical Medicine and Hygiene 92, 527-531.

Menendez, C. (1995). Malaria during pregnancy: a priority area of malaria research and control. Parasitology Today 11, 178-183.

Menendez, C. and Mayor, A. (2007). Congenital malaria: the least known consequence of malaria in pregnancy. Seminars in Fetal and Neonatal Medicine 12, 207-213.

Metenou, S., Suguitan, A. L., Jr., Long, C., Leke, R. G. and Taylor, D. W. (2007). Fetal immune responses to Plasmodium falciparum antigens in a malaria-endemic region of Cameroon. Fournal of Immunology 178, 2770-2777.

Michon, P., Cole-Tobian, J. L., Dabod, E., Schoepflin, S., Igu, J., Susapu, M., Tarongka, N., Zimmerman, P. A., Reeder, J. C., Beeson, J. G., Schofield, L., King, C. L. and Mueller, I. (2007). The risk of malarial infections and disease in Papua New Guinean children. American Fournal of Tropical Medicine and Hygiene 76, 997-1008.

Muirhead-Thomson, R. C. (1951). The distribution of anopheline mosquito bites among different age groups; a new factor in malaria epidemiology. British Medical fournal 1, 1114-1117.

Murungi, L. M., Kamuyu, G., Lowe, B., Bejon, P., Theisen, M., Kinyanjui, S. M., Marsh, K. and Osier, F. H. (2013). A threshold concentration of anti-merozoite antibodies is required for protection from clinical episodes of malaria. Vaccine 31, 3936-3942.

Mutabingwa, T. K., Malle, L. N., Verhave, J. P., Eling, W.M.,

Meuwissen, J. H. and de Geus, A. (1993). Malaria chemosuppression during pregnancy. IV. Its effects on the newborn's passive malaria immunity. Tropical and Geographical Medicine 45, 150-156.

Mutabingwa, T.K., Bolla, M. C., Li, J. L., Domingo, G. J., Li, X., Fried, M. and Duffy, P. E. (2005). Maternal malaria and gravidity interact to modify infant susceptibility to malaria. PLoS Medicine 2, e407.

Mwaniki, M. K., Talbert, A. W., Mturi, F. N., Berkley, J. A., Kager, P., Marsh, K. and Newton, C. R. (2010). Congenital and neonatal malaria in a rural Kenyan district hospital: an eight-year analysis. Malaria Fournal 9, 313

Nhabomba, A. J., Guinovart, C., Jimenez, A., Manaca, M. N., Quinto, L., Cistero, P., Aguilar, R., Barbosa, A., Rodriguez, M. H., Bassat, Q., Aponte, J. J., Mayor, A., Chitnis, C. E., Alonso, P. L. and Dobano, C. (2014). Impact of age of first exposure to Plasmodium falciparum on antibody responses to malaria in children: a randomized, controlled trial in Mozambique. Malaria fournal 13, 121

Nosten, F., Rogerson, S. J., Beeson, J. G., McGready, R., Mutabingwa, T. K. and Brabin, B. (2004). Malaria in pregnancy and the endemicity spectrum: what can we learn? Trends in Parasitology 20, $425-432$

Osier, F. H., Fegan, G., Polley, S. D., Murungi, L., Verra, F., Tetteh, K. K., Lowe, B., Mwangi, T., Bull, P. C., Thomas, A.W., Cavanagh, D. R., McBride, J.S., Lanar, D. E., Mackinnon, M. J., Conway, D. J. and Marsh, K. (2008). Breadth and magnitude of antibody responses to multiple Plasmodium falciparum merozoite antigens are associated with protection from clinical malaria. Infection and Immunity 76, $2240-2248$.
Osier, F. H., Mackinnon, M. J., Crosnier, C., Fegan, G., Kamuyu, G., Wanaguru, M., Ogada, E., McDade, B., Rayner, J. C., Wright, G. J. and Marsh, K. (2014). New antigens for a multicomponent blood-stage malaria vaccine. Science Translational Medicine 6, 247ra102.

Otsyula, N., Angov, E., Bergmann-Leitner, E., Koech, M., Khan, F., Bennett, J., Otieno, L., Cummings, J., Andagalu, B., Tosh, D., Waitumbi, J., Richie, N., Shi, M., Miller, L., Otieno, W., Otieno, G. A., Ware, L., House, B., Godeaux, O., Dubois, M. C., Ogutu, B., Ballou, W. R., Soisson, L., Diggs, C., Cohen, J., Polhemus, M., Heppner, D. G., Jr., Ockenhouse, C.F. and Spring, M. D. (2013). Results from tandem Phase 1 studies evaluating the safety, reactogenicity and immunogenicity of the vaccine candidate antigen Plasmodium falciparum FVO merozoite surface protein-1 (MSP1 (42)) administered intramuscularly with adjuvant system AS01. Malaria fournal 12, 29

Pasvol, G., Weatherall, D. J. and Wilson, R. J. (1977). Effects of foetal haemoglobin on susceptibility of red cells to Plasmodium falciparum. Nature 270, 171-173.

Poespoprodjo, J. R., Fobia, W., Kenangalem, E., Lampah, D. A., Hasanuddin, A., Warikar, N., Sugiarto, P., Tjitra, E., Anstey, N. M. and Price, R. N. (2009). Vivax malaria: a major cause of morbidity in early infancy. Clinical Infectious Diseases 48, 1704-1712.

Port, G. (1980). The relationship of host size to feeding by mosquitoes of the Anopheles gambiae Giles complex (Diptera: Culicidae). Bulletin of Entomological Research 70, 133-144.

Price, R. N., Tjitra, E., Guerra, C. A., Yeung, S., White, N. J. and Anstey, N. M. (2007). Vivax malaria: neglected and not benign. American Fournal of Tropical Medicine Hygiene 77, 79-87.

Quelhas, D., Jimenez, A., Quinto, L., Serra-Casas, E., Mayor, A., Cistero, P., Puyol, L., Wilson, D.W., Richards, J.S., Nhampossa, T., Macete, E., Aide, P., Mandomando, I., Sanz, S., Aponte, J. J., Alonso, P. L., Beeson, J. G., Menendez, C. and Dobano, C. (2011). IgG against Plasmodium falciparum variant surface antigens and growth inhibitory antibodies in Mozambican children receiving intermittent preventive treatment with sulfadoxine-pyrimethamine. Immunobiology 216, 793-802.

Rachas, A., Le Port, A., Cottrell, G., Guerra, J., Choudat, I., Bouscaillou, J., Massougbodji, A. and Garcia, A. (2012). Placental malaria is associated with increased risk of nonmalaria infection during the first 18 months of life in a Beninese population. Clinical Infectious Diseases 55, 672-678.

Rasheed, F. N., Bulmer, J. N., De Francisco, A., Jawla, M.F., Jakobsen, P.H., Jepson, A. and Greenwood, B. M. (1995). Relationships between maternal malaria and malarial immune responses in mothers and neonates. Parasite Immunology 17, 1-10.

Reeder, J. C., Rogerson, S. J., al-Yaman, F., Anders, R. F., Coppel, R. L., Novakovic, S., Alpers, M. P. and Brown, G. V. (1994). Diversity of agglutinating phenotype, cytoadherence, and rosette-forming characteristics of Plasmodium falciparum isolates from Papua New Guinean children. American fournal of Tropical Medicine and Hygiene 51, 45-55.

Remarque, E. J., Roestenberg, M., Younis, S., Walraven, V., van der Werff, N., Faber, B. W., Leroy, O., Sauerwein, R., Kocken, C. H. and Thomas, A.W. (2012). Humoral immune responses to a single allele PfAMA1 vaccine in healthy malaria-naive adults. $P L O S O N E 7$, e38898. Richards, J. S. and Beeson, J. G. (2009). The future for blood-stage vaccines against malaria. Immunology and Cell Biology 87, 377-390.

Richards, J. S., Stanisic, D. I., Fowkes, F. J., Tavul, L., Dabod, E., Thompson, J. K., Kumar, S., Chitnis, C. E., Narum, D. L., Michon, P., Siba, P. M., Cowman, A. F., Mueller, I. and Beeson, J. G. (2010). Association between naturally acquired antibodies to erythrocyte-binding antigens of Plasmodium falciparum and protection from malaria and high-density parasitemia. Clinical Infectious Diseases 51, e50-e60.

Richards, J. S., Arumugam, T. U., Reiling, L., Healer, J., Hodder, A. N., Fowkes, F. J., Cross, N., Langer, C., Takeo, S., Uboldi, A. D., Thompson, J. K., Gilson, P. R., Coppel, R. L., Siba, P. M., King, C. L., Torii, M., Chitnis, C.E., Narum, D. L., Mueller, I., Crabb, B.S., Cowman, A. F., Tsuboi, T. and Beeson, J. G. (2013). Identification and prioritization of merozoite antigens as targets of protective human immunity to Plasmodium falciparum malaria for vaccine and biomarker development. Fournal of Immunology 191, 795-809.

Riley, E. M. (1999). Is T-cell priming required for initiation of pathology in malaria infections? Immunology Today 20, 228-233.

Riley, E. M., Wagner, G. E., Ofori, M.F., Wheeler, J. G., Akanmori, B.D., Tetteh, K., McGuinness, D., Bennett, S., Nkrumah, F. K., Anders, R. F. and Koram, K. A. (2000). Lack of association between maternal antibody and protection of African infants from malaria infection. Infection and Immunity 68, 5856-5863. 
Riley, E. M., Wagner, G.E., Akanmori, B. D. and Koram, K. A. (2001). Do maternally acquired antibodies protect infants from malaria infection? Parasite Immunology 23, 51-59.

Rogerson, S. J., Hviid, L., Duffy, P. E., Leke, R. F. and Taylor, D. W. (2007). Malaria in pregnancy: pathogenesis and immunity. The Lancet Infectious Diseases 7, 105-117.

Roussilhon, C., Oeuvray, C., Muller-Graf, C., Tall, A., Rogier, C., Trape, J. F., Theisen, M., Balde, A., Perignon, J. L. and Druilhe, P. (2007). Long-term clinical protection from falciparum malaria is strongly associated with IgG3 antibodies to merozoite surface protein 3. PLoS Medicine 4, e320.

Rts, S. C. T.P. (2015). Efficacy and safety of RTS,S/AS01 malaria vaccine with or without a booster dose in infants and children in Africa: final results of a phase 3, individually randomised, controlled trial. Lancet 386, 31-45. Schwarz, N. G., Adegnika, A. A., Breitling, L.P., Gabor, J., Agnandji, S. T., Newman, R. D., Lell, B., Issifou, S. Yazdanbakhsh, M., Luty, A. J., Kremsner, P. G. and Grobusch, M. P. (2008). Placental malaria increases malaria risk in the first 30 months of life. Clinical Infectious Diseases 47, 1017-1025.

Sehgal, V. M., Siddjiqui, W. A. and Alpers, M. P. (1989). A seroepidemiological study to evaluate the role of passive maternal immunity to malaria in infants. Transactions of the Royal Society of Tropical Medicine and Hygiene 83(Suppl.), 105-106.

Senn, N., Rarau, P., Stanisic, D. I., Robinson, L., Barnadas, C., Manong, D., Salib, M., Iga, J., Tarongka, N., Ley, S., RosanasUrgell, A., Aponte, J. J., Zimmerman, P. A., Beeson, J. G., Schofield, L., Siba, P., Rogerson, S. J., Reeder, J. C. and Mueller, I. (2012). Intermittent preventive treatment for malaria in Papua New Guinean infants exposed to Plasmodium falciparum and $P$. vivax: a randomized controlled trial. PLoS Medicine 9, e1001195.

Shear, H.L., Grinberg, L., Gilman, J., Fabry, M.E., Stamatoyannopoulos, G., Goldberg, D. E. and Nagel, R. L. (1998)

Transgenic mice expressing human fetal globin are protected from malaria by a novel mechanism. Blood 92, 2520-2526.

Simister, N. E. (2003). Placental transport of immunoglobulin G. Vaccine 21, 3365-3369.

Singh, S., Miura, K., Zhou, H., Muratova, O., Keegan, B., Miles, A., Martin, L. B., Saul, A. J., Miller, L. H. and Long, C. A. (2006). Immunity to recombinant plasmodium falciparum merozoite surface protein 1 (MSP1): protection in Aotus nancymai monkeys strongly correlates with anti-MSP1 antibody titer and in vitro parasite-inhibitory activity. Infection and Immunity 74, 4573-4580.

Smith, J. D. (2014). The role of PfEMP1 adhesion domain classification in Plasmodium falciparum pathogenesis research. Molecular and Biochemical Parasitology 195, 82-87.

Smith, J. D., Chitnis, C. E., Craig, A. G., Roberts, D. J., HudsonTaylor, D. E., Peterson, D. S., Pinches, R., Newbold, C. I. and Miller, L. H. (1995). Switches in expression of Plasmodium falciparum var genes correlate with changes in antigenic and cytoadherent phenotypes of infected erythrocytes. Cell 82, 101-110.

Snow, R. W., Nahlen, B., Palmer, A., Donnelly, C. A., Gupta, S. and Marsh, K. (1998). Risk of severe malaria among African infants: direct evidence of clinical protection during early infancy. The Fournal of Infectious Diseases 177, 819-822.
Spring, M.D., Cummings, J.F., Ockenhouse, C. F., Dutta, S., Reidler, R., Angov, E., Bergmann-Leitner, E., Stewart, V.A., Bittner, S., Juompan, L., Kortepeter, M. G., Nielsen, R., Krzych, U., Tierney, E., Ware, L. A., Dowler, M., Hermsen, C. C., Sauerwein, R. W., de Vlas, S. J., Ofori-Anyinam, O., Lanar, D. E. Williams, J.L., Kester, K.E., Tucker, K., Shi, M., Malkin, E., Long, C., Diggs, C. L., Soisson, L., Dubois, M. C., Ballou, W. R., Cohen, J. and Heppner, D. G., Jr. (2009). Phase 1/2a study of the malaria vaccine candidate apical membrane antigen-1 (AMA-1) administered in adjuvant system AS01B or AS02A. PLoS ONE 4, e5254.

Stanisic, D. I., Fowkes, F. J., Koinari, M., Javati, S., Lin, E. Kiniboro, B., Richards, J.S., Robinson, L. J., Schofield, L. Kazura, J. W., King, C. L., Zimmerman, P., Felger, I., Siba, P. M., Mueller, I. and Beeson, J. G. (2015). Acquisition of antibodies against Plasmodium falciparum merozoites and malaria immunity in young children and the influence of age, force of infection, and magnitude of response. Infection and Immunity 83, 646-660.

Turner, L., Lavstsen, T., Berger, S. S., Wang, C. W., Petersen, J. E., Avril, M., Brazier, A. J., Freeth, J., Jespersen, J. S., Nielsen, M. A. Magistrado, P., Lusingu, J., Smith, J.D., Higgins, M. K. and Theander, T.G. (2013). Severe malaria is associated with parasite binding to endothelial protein C receptor. Nature 498, 502-505.

Van de Perre, P. (2003). Transfer of antibody via mother's milk. Vaccine 21, 3374-3376.

Verhoeff, F.H., Le Cessie, S., Kalanda, B.F., Kazembe, P. N., Broadhead, R. L. and Brabin, B. J. (2004). Post-neonatal infant mortality in Malawi: the importance of maternal health. Annals of Tropical Paediatrics 24, 161-169.

Vestergaard, L.S., Lusingu, J.P., Nielsen, M. A., Mmbando, B.P., Dodoo, D., Akanmori, B. D., Alifrangis, M., Bygbjerg, I. C. Lemnge, M. M., Staalsoe, T., Hviid, L. and Theander, T. G. (2008). Differences in human antibody reactivity to Plasmodium falciparum variant surface antigens are dependent on age and malaria transmission intensity in North-eastern Tanzania. Infection and Immunity 76, 2706-2714.

Wagner, G., Koram, K., McGuinness, D., Bennett, S., Nkrumah, F. and Riley, E. (1998). High incidence of asymptomatic malara infections in a birth cohort of children less than one year of age in Ghana, detected by multicopy gene polymerase chain reaction. American Fournal of Tropical Medicine and Hygiene 59, 115-123.

WHO (2014). World Malaria Report. In World Health Organisation Geneva, Switzerland, WHO Press.

Wilson, P. T., Malhotra, I., Mungai, P., King, C. L. and Dent, A. E. (2013). Transplacentally transferred functional antibodies against Plasmodium falciparum decrease with age. Acta Tropica 128, 149-153. Xi, G., Leke, R. G., Thuita, L. W., Zhou, A., Leke, R. J., Mbu, R. and Taylor, D. W. (2003). Congenital exposure to Plasmodium falciparum antigens: prevalence and antigenic specificity of in utero-produced antimalarial immunoglobulin M antibodies. Infection and Immunity 71, 1242-1246.

Zhou, Z., Xiao, L., Branch, O.H., Kariuki, S., Nahlen, B. L. and Lal, A. A. (2002). Antibody responses to repetitive epitopes of the circumsporozoite protein, liver stage antigen-1, and merozoite surface protein-2 in infants residing in a Plasmodium falciparum-hyperendemic area of western Kenya. XIII. Asembo Bay Cohort Project. American fournal of Tropical Medicine and Hygiene 66, 7-12. 